\title{
Corticotropin-Releasing Hormone Antagonists, Astressin B and Antalarmin: Differing Profiles of Activity in Rhesus Monkeys
}

\author{
Jillian H Broadbear*,', Gail Winger', Jean E Rivier², Kenner C Rice ${ }^{3}$ and James H Woods ${ }^{1,4}$ \\ 'Department of Pharmacology, University of Michigan Medical School, Ann Arbor, MI, USA; ${ }^{2}$ The Salk Institute for Biological Studies, La Jolla, CA, \\ USA; ${ }^{3}$ National Institutes of Health, NIDDK, Bethesda, MD, USA; ${ }^{4}$ Department of Psychology, University of Michigan Medical School, Ann Arbor, \\ MI, USA
}

\begin{abstract}
The present study compares the activity of two chemically distinct corticotropin-releasing hormone $(\mathrm{CRH})$ antagonists at the level of the pituitary gland in rhesus monkeys, using exogenous $\mathrm{CRH}$-stimulated increases in adrenocorticotropin (ACTH) and cortisol. Of chief interest was whether the $\mathrm{CRH}-\mathrm{RI}$-selective pyrrolopyrimidine, antalarmin, shown previously to have activity in the central nervous system (CNS), would differ in its antagonist profile from the CRH-RI- \& 2-selective peptide, astressin B, which is unlikely to have access to the CNS following systemic administration. Nine rhesus monkeys (eight male), each with an indwelling venous catheter, were subjects in this study. Astressin B (0.00I, 0.003, 0.03, 0.1 , and $0.3 \mathrm{mg} / \mathrm{kg}$ ) or antalarmin (1.0, 3.2, and $10 \mathrm{mg} / \mathrm{kg})$ was administered as an intravenous (i.v.) pretreatment 15 min prior to administration of I or $10 \mu \mathrm{g} / \mathrm{kg}$ i.v. $\mathrm{CRH}$. Antalarmin $(10 \mathrm{mg} / \mathrm{kg})$ was also administered alone on six occasions and its effects on behavior as well as on ACTH and cortisol levels were measured. Astressin B was assessed following i.v. and intracisternal (i.c.) administration. Astressin B dose-dependently abolished the $\mathrm{CRH}$-stimulated $\mathrm{ACTH}$ and cortisol responses, with an antagonist effect lasting in excess of $24 \mathrm{~h}$. Astressin B was approximately 300-times more potent when given i.c. than when it was administered via the i.v. route. By contrast, antalarmin antagonized the effects of $\mathrm{CRH}$ on ACTH but not cortisol at $1.0 \mathrm{and} 3.2 \mathrm{mg} / \mathrm{kg}$. At a larger dose, antalarmin stimulated ACTH and cortisol release and produced behavioral sedation. These latter effects diminished with repeated administration of antalarmin. The differences between astressin $\mathrm{B}$ and antalarmin may be due either to non- $\mathrm{CRH}$ receptormediated effects of antalarmin or to a complex interaction of antalarmin's effects at both central and peripheral CRH receptors. Neuropsychopharmacology (2004) 29, I I I2-I I2I, advance online publication, 3 March 2004; doi: I 0.1038/sj.npp. I 3004 I0
\end{abstract}

Keywords: rhesus monkey (Macaca mulatta); CRH antagonist; antalarmin; astressin B; cortisol; $\mathrm{ACTH}$

\section{INTRODUCTION}

Several recent publications have shown that hyperactivity of the hypothalamic-pituitary-adrenal (HPA) axis may often accompany a diagnosis of depression and anxiety (Nemeroff, 1996; Holsboer, 1998; McEwen, 2000). There is a growing body of evidence that implicates abnormal HPA functioning in the etiology of a variety of affective disorders. The HPA axis has also been suggested as a target for the treatment of substance abuse, as drug-related behaviors can

\footnotetext{
*Correspondence: Current address: Dr J H Broadbear, Department of Physiology, Monash University, Building I3F, Clayton, Vic 3800, Australia, Tel: + II 6139905 2557, Fax: + II 6139905 2547, E-mail: jillian.broadbear@med.monash.edu

Reprint requests to JH Woods, Department Pharmacology, University of Michigan, I30I MSRB 3, Ann Arbor, MI 48I09-0632, USA.

Received 23 October 2003; revised 09 December 2003; accepted 13 January 2004

Online publication: 19 January 2004 at http://www.acnp.org/citations/ Npp0 I 190402386/default.pdf
}

be disrupted by treatment with corticotropin-releasing hormone (CRH) antagonists (Goeders, 1997; McCarthy et al, 1999). Treatment with the CRH antagonist CP154,526 has been reported to reduce the amount of cocaine self-administered by rats (Goeders and Guerin, 2000), and attenuate the reinstatement of drug-related behaviors for cocaine (Shaham et al, 1998) and opioids (Lu et al, 2000). These findings have helped fuel the recent investigation of $\mathrm{CRH}$ antagonists for use in the treatment of these disorders.

A variety of $\mathrm{CRH}$ antagonists have been synthesized, beginning with the early modifications of CRH itself that resulted in $\alpha$-helical $\mathrm{CRH}_{(9-41)}$ (Rivier et al, 1984) and D-Phe $\mathrm{CRH}_{(12-41)}$ (Hernandez et al, 1993; Menzaghi et al, 1994), and extending to the more recent analogs, astressin (Gulyas et al, 1995) and the longer-lasting astressin B (Rivier et al, 1999). Nonpeptidic compounds, the so-called 'small molecule' CRH-R1 selective antagonists, such as CP-154,526 (Schulz et al, 1996), its methyl analog, antalarmin (Webster et al, 1996; see also review by McCarthy et al, 1999), and SSR125543A (Griebel et al, 2002) have been investigated 
preclinically using animal models of depression and anxiety. Currently, this literature is dominated by rodent studies. One exception to this was a study carried out in rhesus monkeys (Habib et al, 2000) using antalarmin. In this paper, the pharmacokinetic profile of antalarmin following intravenous (i.v.) and oral administration was assessed, as were the effects of oral administration of antalarmin on both the HPA and behavioral responses to a stressor. Antalarmin was detected in cerebrospinal fluid (CSF) following oral administration, indicating that antalarmin has access to the central nervous system (CNS) when given peripherally. A social stressor that involved placing two unfamiliar males in a single cage separated only by a transparent wall was used to measure the anxiolytic effects of antalarmin. Following antalarmin pretreatment, Habib et al (2000) reported a significant reduction in anxietyrelated behaviors observed during the $30 \mathrm{~min}$ that monkeys were placed in close proximity. Significant reductions in both adrenocorticotropin (ACTH) and cortisol levels in plasma were reported following the social stressor.

The CRH-R1 receptor specificity of antalarmin is based on in vitro work in which antalarmin displaced ${ }^{125} \mathrm{I}$-oCRH binding in rat pituitary, frontal cortex, and cerebellum where CRH-R1 receptors predominate, but not in heart where CRH-R2 receptors predominate (Webster et al, 1996). However, the in vivo evidence that antalarmin produces a CRH-R1 blockade at the pituitary level in rats is weak, as the $\mathrm{CRH}$-antagonist effects of antalarmin do not appear to be dose-dependent, nor was HPA antagonism demonstrated following application of stressors whose behavioral effects antalarmin has been reported to attenuate (Deak et al, 1999; Wong et al, 1999). In non-human primates, however, antalarmin produced a significant attenuation of stressinduced ACTH and cortisol release in monkeys as well as a reduction in the behavioral signs of stress (Habib et al, 2000).

Although there are fewer publications to date concerning astressin $\mathrm{B}$, these nevertheless provide convincing evidence that acute administration of astressin $B$ results in a timeand dose-dependent blockade of ACTH release in adrenalectomized rats (Rivier et al, 1999), as well as in rats exposed to inescapable footshock or treated with h/r CRH, lipopolysaccharide or intragastric alcohol (Rivier et al, 2003). Although astressin B, a peptidic CRH antagonist, is unlikely to cross the blood-brain barrier following peripheral administration, it clearly produces a robust blockade of pituitary $\mathrm{CRH}_{1}$ receptors.

To date, there have been no direct comparisons of nonpeptidic and peptidic $\mathrm{CRH}$ antagonists at the level of the HPA axis. Blocking CRH-stimulated increases in ACTH and cortisol is a fundamental test of the pituitary activity of $\mathrm{CRH}$ antagonists. It is predicted that the differences in chemical structure as well as in distribution between the CNS and periphery following i.v. administration of antalarmin or astressin B will result in divergent profiles of pituitary CRHreceptor antagonism. In the present study, the effects of antalarmin and astressin B were compared in rhesus monkeys using i.v. injection of $\mathrm{CRH}$ as the stimulus and ACTH and cortisol levels as the dependent measures. The effects that antalarmin treatment had on behavioral and HPA axis activity were also measured, as were the effects of repeated treatment with antalarmin. Astressin B was evaluated for its duration of antagonist activity, as well as for its effectiveness using central and systemic routes of administration.

\section{METHODS}

\section{Subjects}

Eight adult male rhesus monkeys (Macaca mulatta), seven intact and one castrate (Monkey 2595), weighing between 10.0 and $15.1 \mathrm{~kg}$, and one intact female monkey, weighing $6.3 \mathrm{~kg}$, were the subjects for this study. Most subjects had a drug self-administration history with two or more classes of drug, including cocaine and methohexital. The duration of drug-taking history averaged 2.5 years, with a range from 3 months to 5 years. The monkeys continued to selfadminister drug or saline during the course of the present study. Small doses of drug (saline, $0.03 \mathrm{mg} / \mathrm{kg} / \mathrm{inj}$ cocaine for a maximum of 13 injections, or $0.1 \mathrm{mg} / \mathrm{kg} / \mathrm{inj}$ methohexital for a maximum of between 90 and 140 injections) were available during each of two, 2 -h daily sessions. Saline was substituted for drug during half of the self-administration sessions, and apart from a decrease in drug-maintained behavior, no behavioral disruption was evident when drug was not available. The monkeys were randomly assigned to the different treatment groups, so any effect of their different histories was most likely negated. Cocaine and methohexital have short half-lives, averaging $0.8 \pm 0.2$ and $4 \pm 2 \mathrm{~h}$ respectively in humans. Each test day was preceeded by at least a $24 \mathrm{~h}$ drug-free period. Three of the monkeys were antalarmin-naive at the time of this study.

\section{Monkey Housing}

Each monkey was individually housed in a stainless steel cage measuring $83.3 \times 76.2 \times 91.4 \mathrm{~cm}^{3}$ deep (Bryan Research Equipment Corporation, Bryan, TX) located in a laboratory that contained a total of 24 similarly housed monkeys. The temperature in the room was maintained at $21 \pm 1^{\circ} \mathrm{C}$, and lights were illuminated from 0630 until 1930 daily. The monkeys were fed eight to 12 Purina Monkey Chow biscuits twice daily to maintain normal adult weight and water was freely available.

\section{Surgical Procedures}

Each monkey had an indwelling venous catheter in a femoral, internal, or external jugular vein. Catheters were inserted during aseptic surgery under ketamine $(10 \mathrm{mg} / \mathrm{kg})$ and xylazine $(2 \mathrm{mg} / \mathrm{kg})$ anesthesia. Following placement in the vein, the catheter was guided subcutaneously to the midscapular region where it was externalized. The external portion of the catheter was protected inside the cage by a flexible stainless steel tether, with one end attached to a double layer polyester jacket (Lomir, New York, NY) worn by the monkey and the other bolted to the rear of the cage. Monkeys were treated postoperatively with the analgesic, buprenorphine, as needed. In addition, they were treated with the broad-spectrum antibiotic, chloromycetin (Chloramphenicol), at the time of surgery and twice daily for 3 days postsurgery. Behavior and food intake were monitored regularly throughout each day, a physical examination was 
performed under ketamine anesthesia every 2 weeks, no experiments were conducted and expert veterinary care was available on an on-call basis if illness was suspected, or while monkeys were being treated for any illness. Test treatments were administered and blood samples were obtained by accessing the i.v. catheter from the rear of the cage with minimal disturbance to each monkey. Each monkey was tested in its home cage. All studies reported here were carried out in accordance with the Guide for the Care and Use of Laboratory Animals as adopted and promulgated by the National Institutes of Health.

\section{Study Design}

HPA response following $C R H$ injection. A total of seven male monkeys received i.v. CRH (1.0 and $/$ or $10 \mu \mathrm{g} / \mathrm{kg}$; eg Broadbear et al, 1999b). Three monkeys were selected to receive pretreatment with antalarmin $(1.0,3.2$, and $10 \mathrm{mg} /$ $\mathrm{kg}$; eg Broadbear et al, 2002) and the remaining four received pretreatment with astressin $B(0.001,0.003,0.03$, $0.1(n=3)$, and $0.3 \mathrm{mg} / \mathrm{kg} ;$ eg Broadbear et al, 1999a). The order in which antagonist doses were administered was randomized. The pretreatment and blood sampling times for the antagonist + CRH studies were based on the above studies (Table 1).

Samples continued to be drawn, first at 10 , then 15,30 , and $60 \mathrm{~min}$ intervals for the next $4-7 \mathrm{~h}$. The first blood sampling took place between 0900 and 1000 . The details regarding sample collection and processing for the measurement of ACTH and cortisol levels in plasma are described below.

Procedure for the intracisternal (i.c.) administration of astressin B. Three monkeys were selected to receive i.c. injections of astressin B. The monkeys were briefly anesthetized with $4 \mathrm{mg} / \mathrm{kg}$ i.v. methohexital followed by booster injections of $2 \mathrm{mg} / \mathrm{kg}$ methohexital. Each booster injection produced anesthesia lasting 5-8 min during which the animals were motionless and unresponsive to touch. Following anesthetization with methohexital, the area on the back of the head and neck was shaved and the skin was cleaned by alternating with povidone-iodine (Vedco Inc., St Joseph, MO) and alcohol-soaked gauze squares. While an assistant held each animal securely, a spinal needle (22 gauge, $1 \frac{1}{2}$ inch; Becton Dickenson, Franklin Lakes, NJ) was slowly directed toward the cisterna magna until
CSF returned through the needle. A syringe containing $0.1 \mu \mathrm{g}$ astressin $\mathrm{B}$ was then attached to the needle and injected in a volume of $0.5 \mathrm{ml}$. Each monkey recovered normal function within $30 \mathrm{~min}$.

In order to evaluate the effect of methohexital anesthesia on the subsequent ACTH and cortisol response to i.v. $\mathrm{CRH}$, five male monkeys, including the three that received i.c. astressin B injections, were anesthetized and treated exactly the same way as described in the previous paragraph, except that a spinal need was not inserted and i.c. astressin $B$ was not administered. After $40 \mathrm{~min}, 3.2 \mu \mathrm{g} / \mathrm{kg} \mathrm{CRH}$ was administered i.v.. Blood was sampled prior to methohexital administration, following methohexital administration, prior to CRH administration, and then over $4 \mathrm{~h}$ following $\mathrm{CRH}$ administration.

HPA response following repeated treatment with antalarmin. To evaluate the effects of frequent administration of antalarmin alone or as a pretreatment before the injection of $\mathrm{CRH}$, two experiments were conducted. In the first, four monkeys were tested using the following protocol (Table 2).

In the second experiment, an additional three antalarminnaive monkeys, two of which were male, received $10 \mathrm{mg} / \mathrm{kg}$ i.v. antalarmin on six occasions at weekly intervals. The effects of saline and vehicle treatments on ACTH and cortisol were tested before and after the 6 weeks of antalarmin tests. These animals did not receive CRH injec tions. Blood samples in both of these studies were obtained at the times described above and were used for the measurement of ACTH and cortisol levels.

Blood collection and handling. Prior to drawing each blood sample, a $3 \mathrm{~cm}^{3}$ syringe was used to empty the contents of the catheter and this fluid was discarded. Blood samples $(1.1-1.4 \mathrm{ml}$ ) were placed in a $2 \mathrm{ml}$ Vacutainer (Becton

Table 2 Chronic Antalarmin Experiment

\begin{tabular}{lc}
\hline Experimental days & Treatment (each administered i.v.) \\
\hline 0 and 21 & $10 \mu g / \mathrm{kg} \mathrm{CRH}$ \\
$\mathrm{I}, 4,7$, and 12 & $3.2 \mathrm{mg} / \mathrm{kg}$ antalarmin \\
2,9 , and 14 & $3.2 \mathrm{mg} / \mathrm{kg}$ antalarmin $+10 \mu g / \mathrm{kg} \mathrm{CRH}$
\end{tabular}

Table I Experiment Timeline for Antagonist + CRH Studies

\begin{tabular}{|c|c|c|c|c|c|c|c|}
\hline Time (min) and drug & -25 & -20 & -I5 (or $24 \mathrm{~h}$ for astressin B) & -10 & -2 & 0 & Next 4-7 h \\
\hline \multicolumn{8}{|c|}{ I.v. pretreatment with antalarmin or astressin B } \\
\hline I.v. antalarmin & Blood sample & Blood sample & Antalarmin pretreatment & Blood sample & Blood sample & $\mathrm{CRH}$ treatment & Blood sampling \\
\hline I.v. astressin B & Blood sample & Blood sample & Astressin B pretreatment & Blood sample & Blood sample & $\mathrm{CRH}$ treatment & Blood sampling \\
\hline Time (min) and drug & -60 & -50 & -40 & -10 & -2 & 0 & Next 4-7 h \\
\hline \multicolumn{8}{|c|}{ Intracisternal pretreatment with astressin B } \\
\hline I.v. antalarmin & Blood sample & Blood sample & Astressin B pretreatment & Blood sample & Blood sample & $\mathrm{CRH}$ treatment & Blood sampling \\
\hline
\end{tabular}


Dickenson and Company, Franklin Lakes, NJ) containing $0.04 \mathrm{ml}$ of $7.5 \%$ EDTA and immediately placed on ice. After a blood sample was drawn, $1.5-3 \mathrm{ml}$ of $30 \mathrm{U} / \mathrm{ml}$ heparinsaline solution was injected into the catheter. A maximum of $40 \mathrm{ml}$ of blood was drawn over $8 \mathrm{~h}$ in each experiment, well within the $10 \mathrm{ml} / \mathrm{kg}$ guideline recommended by the University of Michigan Committee on Use and Care of Animals.

Blood samples were centrifuged at 5000 RPM for $5 \mathrm{~min}$ at $4{ }^{\circ} \mathrm{C}$ and then the plasma $(0.7 \mathrm{ml})$ was pipetted into $2 \mathrm{ml}$ Cryovials (Corning Incorporated, Corning, NY) and stored at $-80^{\circ} \mathrm{C}$ until assay. ACTH and cortisol levels were determined using commercially available radioimmunoassay kits (cortisol: Diagnostic Products Corporation, Los Angeles, CA; ACTH: Nichols Institute Diagnostics, San Juan Capistrano, CA). The limit of detection of the cortisol assay was $0.2 \mu \mathrm{g} / \mathrm{dl}$, while the intra and interassay coefficients of variation were 5 and $6.5 \%$ respectively. The limit of detection for the ACTH assay was $0.5 \mathrm{pg} / \mathrm{ml}$, with intraand inter-assay coefficients of variation of 3 and $7 \%$ respectively.

\section{Drugs}

$\mathrm{CRH}$ (human/rat corticotropin releasing hormone) and astressin B were provided by JE Rivier (Salk Institute, La Jolla, CA). Astressin B and CRH were both water-soluble. Antalarmin (provided by KC Rice at NIDDK, Bethesda, MD) was solubilized immediately before use in a vehicle of one part ethanol, one part emulphor, and nine parts sterile water at a concentration of $20 \mathrm{mg} / \mathrm{ml}$ antalarmin. Methohexital was purchased from Ace Surgical Supplies (Brockton, MA) and diluted with sterile water.

\section{Data Analysis}

The raw cortisol and ACTH data, representing the HPA response to the $\mathrm{CRH}$ injection after pretreatment with astressin $\mathrm{B}(0.3,0.03$, and $0.003 \mathrm{mg} / \mathrm{kg})$ or antalarmin, were averaged and plotted for presentation. ACTH and cortisol results were standardized for each subject prior to statistical analysis. Standardization involved averaging the baseline values and subtracting them from post-treatment samples to yield a difference score. This enabled direct comparison of the CRH-stimulated changes in HPA axis activity across subjects and treatment days. Data for the repeated antalarmin injection studies were transformed to area under curve (AUC) values. AUC provides an estimate of the total cortisol ( $\mu \mathrm{g} \mathrm{min} / \mathrm{dl})$ or ACTH $(\mathrm{pg} \mathrm{min} / \mathrm{ml}$ ) release relative to basal levels during the $4 \mathrm{~h}$ sampling time following the $\mathrm{CRH}$ injection. AUC values were calculated using the trapezoidal rule (eg Tallarida and Murray, 1987) on a Microsoft Excel spreadsheet.

\section{Statistics}

All data are presented as mean \pm standard error of the mean (SEM). Repeated measures analyses of variance (ANOVA), in which treatment and time were the within-subject variables, were conducted using standardized cortisol and ACTH data (see Data Analysis). Where appropriate, post hoc pairwise comparisons using the Tukey Honest Signi- ficant Difference test of significance $(p<0.05)$ were carried out (Statistica v.5.0, Statsoft, Tulsa, OK).

\section{RESULTS}

\section{$\mathrm{CRH}+$ Astressin B Pretreatment}

Pretreatment with astressin B dose-dependently attenuated the rises in ACTH and cortisol levels that were stimulated by the i.v. administration of $10 \mu \mathrm{g} / \mathrm{kg} \mathrm{CRH}$ (Figure 1). In the case of ACTH, CRH administration resulted in a rise of $222.4 \pm 61.8 \mathrm{pg} / \mathrm{ml}$ from a baseline of $11.7 \pm 2.5 \mathrm{pg} / \mathrm{ml}$ (Figure 1, upper panel). There was a significant effect of pretreatment with astressin $\mathrm{B}\left(\mathrm{F}_{5,10}=3.8, p=0.03\right)$, with $0.3,0.03$, and $0.003 \mathrm{mg} / \mathrm{kg}$ astressin B significantly attenuating the ACTH response relative to $\mathrm{CRH}$ alone $(p<0.05)$. There was also a significant sampling time effect $\left(\mathrm{F}_{9,18}=5.23, \quad p=0.001\right)$ as well as an interaction between treatment and sampling time $\left(\mathrm{F}_{45,90}=2.70\right.$, $p<0.001)$.

In the case of cortisol, $\mathrm{CRH}$ administration resulted in a rise of $21.3 \pm 3.3 \mathrm{ng} / \mathrm{ml}$ from a baseline of $12.3 \pm 1.9 \mathrm{ng} / \mathrm{ml}$ (Figure 1, lower panel). There was a significant effect of pretreatment with astressin $\mathrm{B}\left(\mathrm{F}_{5,10}=9.74, p=0.001\right)$, with 0.3 and $0.03 \mathrm{mg} / \mathrm{kg}$ astressin $\mathrm{B}$ dose dependently attenuating the cortisol response relative to either $\mathrm{CRH}$ alone, or to $\mathrm{CRH}$ following pretreatment with $0.003 \mathrm{mg} / \mathrm{kg}$ astressin $\mathrm{B}$ $(p<0.05)$. There was also a significant interaction between treatment and sampling time $\left(\mathrm{F}_{45,90}=1.88, p=0.006\right)$.

In order to assess duration of antagonist action, the effects of astressin B were evaluated when astressin B was given $15 \mathrm{~min}$ or $24 \mathrm{~h}$ prior to administration of $10 \mu \mathrm{g} / \mathrm{kg}$ $\mathrm{CRH}$ (Figure 2). When given $15 \mathrm{~min}$ before $\mathrm{CRH}, 0.1 \mathrm{mg} / \mathrm{kg}$ astressin B attenuated the cortisol (45-240, $360 \mathrm{~min}$; $p<0.05)$ and ACTH $(15-180 \mathrm{~min} ; p<0.05)$ response to $\mathrm{CRH}$. This blockade was still present when measured $24 \mathrm{~h}$ after the administration of astressin B, but was significant at fewer sampling times.

The effectiveness of astressin $\mathrm{B}$ as a $\mathrm{CRH}$ receptor antagonist was compared following its administration by two different routes, i.v. and i.c. (Figure 3). The brief anesthesia with the short-acting barbiturate, methohexital ( $4 \mathrm{mg} / \mathrm{kg}$ with a $2 \mathrm{mg} / \mathrm{kg}$ booster), that was required for delivery of the i.c. injection, was evaluated and found to have no effect on the subsequent HPA response to i.v. CRH $40 \mathrm{~min}$ later (data not shown). I.v. $(3.0 \mu \mathrm{g} / \mathrm{kg})$ and i.c. astressin $\mathrm{B}(0.01 \mu \mathrm{g} / \mathrm{kg})$ produced an overall attenuation of the ACTH $\left(\mathrm{F}_{2,4}=6.52, p<0.05\right)$ and cortisol $\left(\mathrm{F}_{2,2}=21.88\right.$, $p<0.05)$ responses to $\mathrm{CRH}$. Whereas both treatments attenuated ACTH and cortisol relative to when CRH was administered alone $(p<0.05)$, the treatments did not differ from one another. There was an interaction between treatment and time for ACTH levels $\left(\mathrm{F}_{16,32}=2.65\right.$, $p<0.01$ ), whereby administration of astressin $\mathrm{B}$ by both routes attenuated the ACTH response to $\mathrm{CRH}$ at sampling times between 15 and $120 \mathrm{~min}(p<0.05$; Figure 3, upper panel). These results indicate that astressin $B$ may be up to 300 -fold more potent when given by the i.c. (central) route than the i.v. (peripheral) route. 

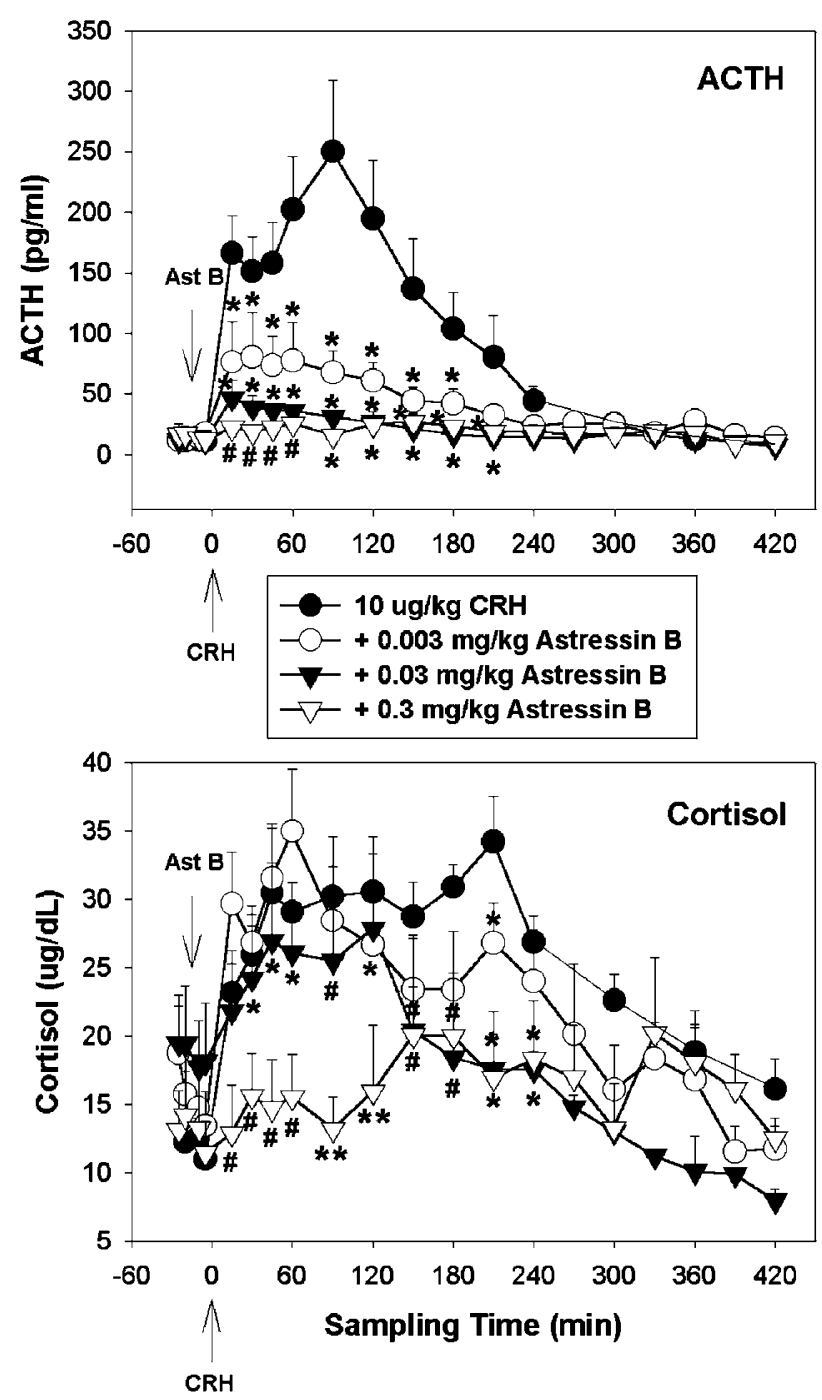

Figure I Averaged ACTH (upper panel) and cortisol (lower panel) levels in plasma following i.v. administration of $10 \mu \mathrm{g} / \mathrm{kg} \mathrm{CRH}$ at time 0 . Male rhesus monkeys $(n=4)$ received $\mathrm{CRH}$ alone or $15 \mathrm{~min}$ after i.v. pretreatment with the $\mathrm{CRH}$ antagonist astressin $\mathrm{B}(0.3,0.03$, or $0.003 \mathrm{mg} /$ $\mathrm{kg})$. $\mathrm{CRH}$-stimulated $\mathrm{ACTH}$ and cortisol levels were attenuated by prior treatment with astressin B (* vs CRH only; \# vs CRH and $0.003 \mathrm{mg} / \mathrm{kg}$ astressin $\mathrm{B}$; ** vs $\mathrm{CRH}, 0.03$ and $0.003 \mathrm{mg} / \mathrm{kg}$ astressin $\mathrm{B}, p<0.05)$. Data for $\mathrm{CRH}$ plus the 0.1 and $0.001 \mathrm{mg} / \mathrm{kg}$ doses of astressin $B$ are not plotted.

\section{$\mathrm{CRH}+$ Antalarmin Pretreatment}

There was a significant attenuation of $\mathrm{CRH}$-stimulated ACTH levels following antalarmin pretreatment $\left(\mathrm{F}_{3,6}=5.66\right.$, $p<0.05$; Figure 4, upper panel). Administration of 1.0 and $3.2 \mathrm{mg} / \mathrm{kg}$ antalarmin attenuated the $\mathrm{CRH}$-induced increase in ACTH relative to when $\mathrm{CRH}$ was administered alone $(p<0.05)$. At a higher dose $(10 \mathrm{mg} / \mathrm{kg})$, antalarmin was a less effective antagonist of CRH-stimulated ACTH secretion than it was at lower doses. Despite the clear attenuation of ACTH following antalarmin pretreatment, antalarmin had no effect on CRH-stimulated cortisol levels (Figure 4, lower panel). Whereas there was no difference between the preantalarmin cortisol levels on the different treatment days, there was a dose-dependent elevation in cortisol levels 5 and
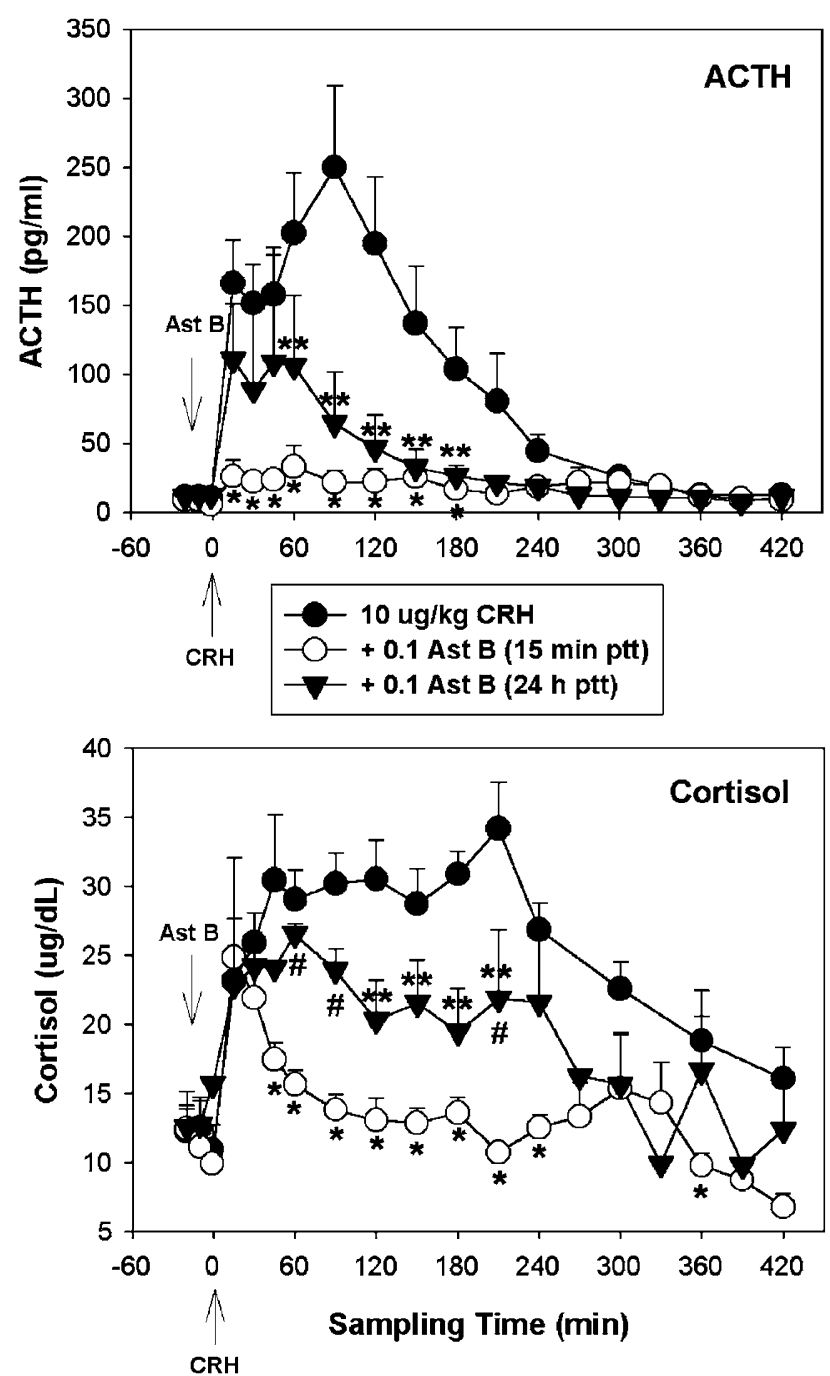

Figure 2 Plasma cortisol and ACTH levels following a single i.v. injection of $10 \mu \mathrm{g} / \mathrm{kg} \mathrm{CRH}$ alone $(n=4)$, or after $15 \mathrm{~min}(n=4)$ or $24 \mathrm{~h}$ pretreatment $(n=3)$ with $0.1 \mathrm{mg} / \mathrm{kg}$ astressin B. At both $15 \mathrm{~min}$ and $24 \mathrm{~h}$, astressin B pretreatment attenuated the cortisol and $\mathrm{ACTH}$ responses to $\mathrm{CRH}$ injection (* $15 \mathrm{~min}$ ptt relative to $\mathrm{CRH}$ alone; $* * 24 \mathrm{~h}$ ptt relative to $\mathrm{CRH}$ alone; \# $15 \mathrm{~min}$ ptt vs $24 \mathrm{~h}$ ptt; $p<0.05)$.

13 min after antalarmin pretreatment, before $\mathrm{CRH}$ was administered at time $0\left(\mathrm{~F}_{3,6}=9.59, p=0.01\right)$. Post hoc analysis indicated that the 3.2 and $10 \mathrm{mg} / \mathrm{kg}$ antalarmin doses elevated cortisol levels significantly above those associated with 0 or $1.0 \mathrm{mg} / \mathrm{kg}$ antalarmin pretreatment $(p<0.05)$, and that the $10 \mathrm{mg} / \mathrm{kg}$ antalarmin dose elevated cortisol significantly with respect to $0,1.0$, and $3.2 \mathrm{mg} / \mathrm{kg}$ antalarmin $(p<0.05)$.

\section{HPA Response Following Repeated Treatment with Antalarmin}

Experiment 1. Antalarmin $(3.2 \mathrm{mg} / \mathrm{kg})$ was administered on several occasions, either alone or prior to $10 \mu \mathrm{g} / \mathrm{kg}$ $\mathrm{CRH}$ administration (Figure 5). $\mathrm{CRH}$ alone significantly 

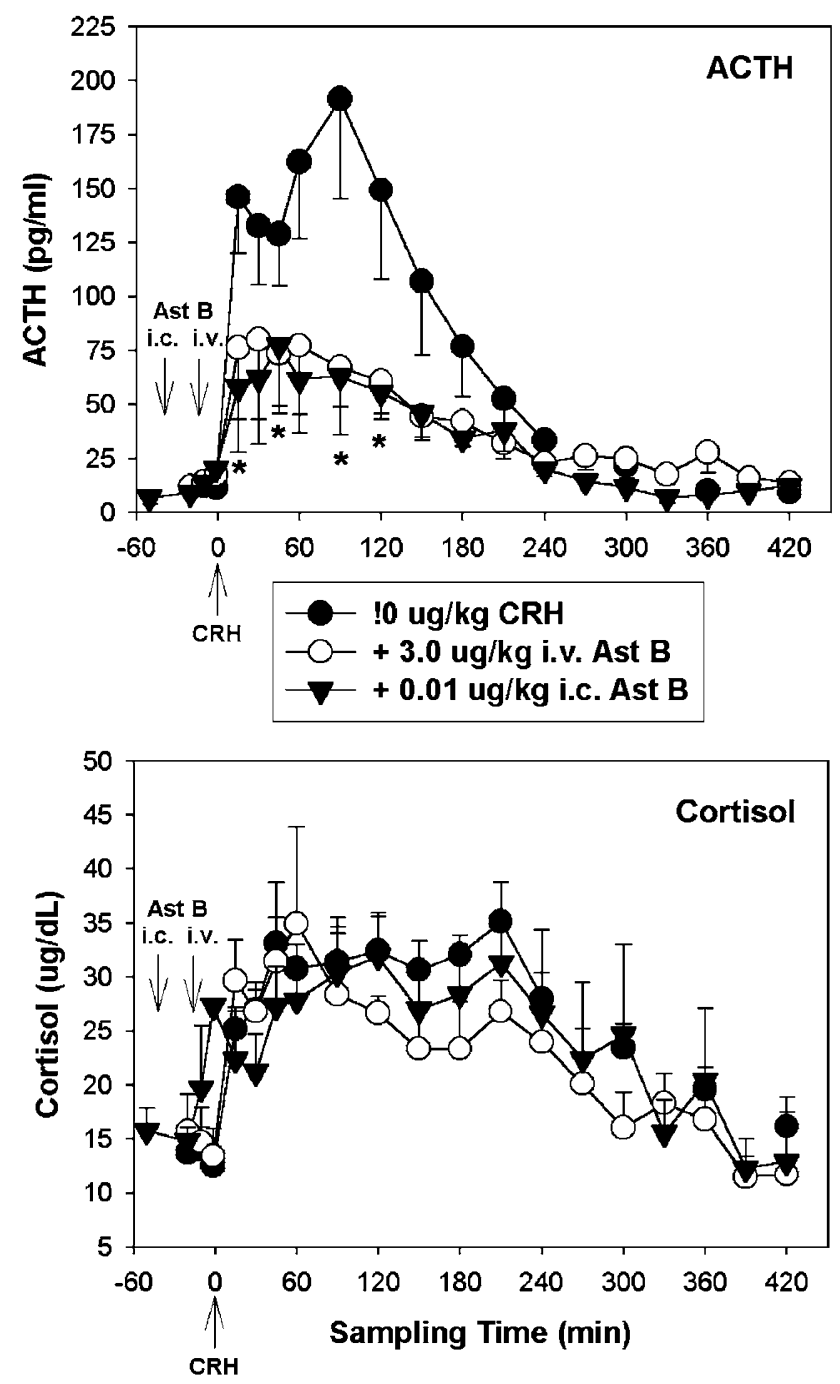

Figure 3 Comparison of the effects of i.v. or i.c. injections of astressin $B$ on $\mathrm{CRH}$-stimulated cortisol and ACTH release $(n=3)$. Astressin B $(3.0 \mu \mathrm{g} /$ $\mathrm{kg}$ i.v.) was administered $15 \mathrm{~min}$ prior to $\mathrm{CRH}$ administration, whereas $0.01 \mu \mathrm{g} / \mathrm{kg}$ i.c. astressin B was administered under methohexital anesthesia $40 \mathrm{~min}$ prior to $\mathrm{CRH}$. Whereas both pretreatments produced an attenuation of the ACTH $\left(F_{2,4}=6.52, \quad p<0.05 *\right)$ and cortisol $\left(F_{2,2}=21.88, p<0.05\right)$ responses to $\mathrm{CRH}$ relative to when $\mathrm{CRH}$ was administered alone, there was no difference between the treatments in their effects on $\mathrm{CRH}$-stimulated cortisol and ACTH. The i.c. route of administration was approximately 300 -fold more potent than the i.v. route in producing a blockade of the $\mathrm{CRH}$-stimulated release of $\mathrm{ACTH}$.

increased both ACTH $\left(\mathrm{F}_{2,6}=12.60, p<0.01\right)$ and cortisol release $\left(\mathrm{F}_{2,6}=42.38, p<0.001\right)$ when given on days 0 and 21 . When given alone on days $1,4,7$, and 12 , antalarmin $(3.2 \mathrm{mg} / \mathrm{kg})$ produced consistent, nonsignificant decreases in ACTH and cortisol. When given prior to administration of $10 \mu \mathrm{g} / \mathrm{kg}$ CRH on days 2,9 , and 14 , antalarmin $(3.2 \mathrm{mg} /$ $\mathrm{kg}$ ) produced significant decreases in ACTH release $(p<0.05)$, but no change in cortisol levels. Antalarmin was also evaluated in three subjects using the same experimental protocol but with a lower dose of CRH $(1 \mu \mathrm{g} / \mathrm{kg})$. This dose of CRH produced a mean cortisol increase of $15.4 \pm 3.3 \mathrm{ng} / \mathrm{ml}$, and increased ACTH levels by $35.3 \pm 14.8 \mathrm{pg} / \mathrm{ml}$. Two doses of antalarmin $(1.0$ and $3.2 \mathrm{mg} /$ $\mathrm{kg}$ ) were evaluated. Neither dose of antalarmin significantly
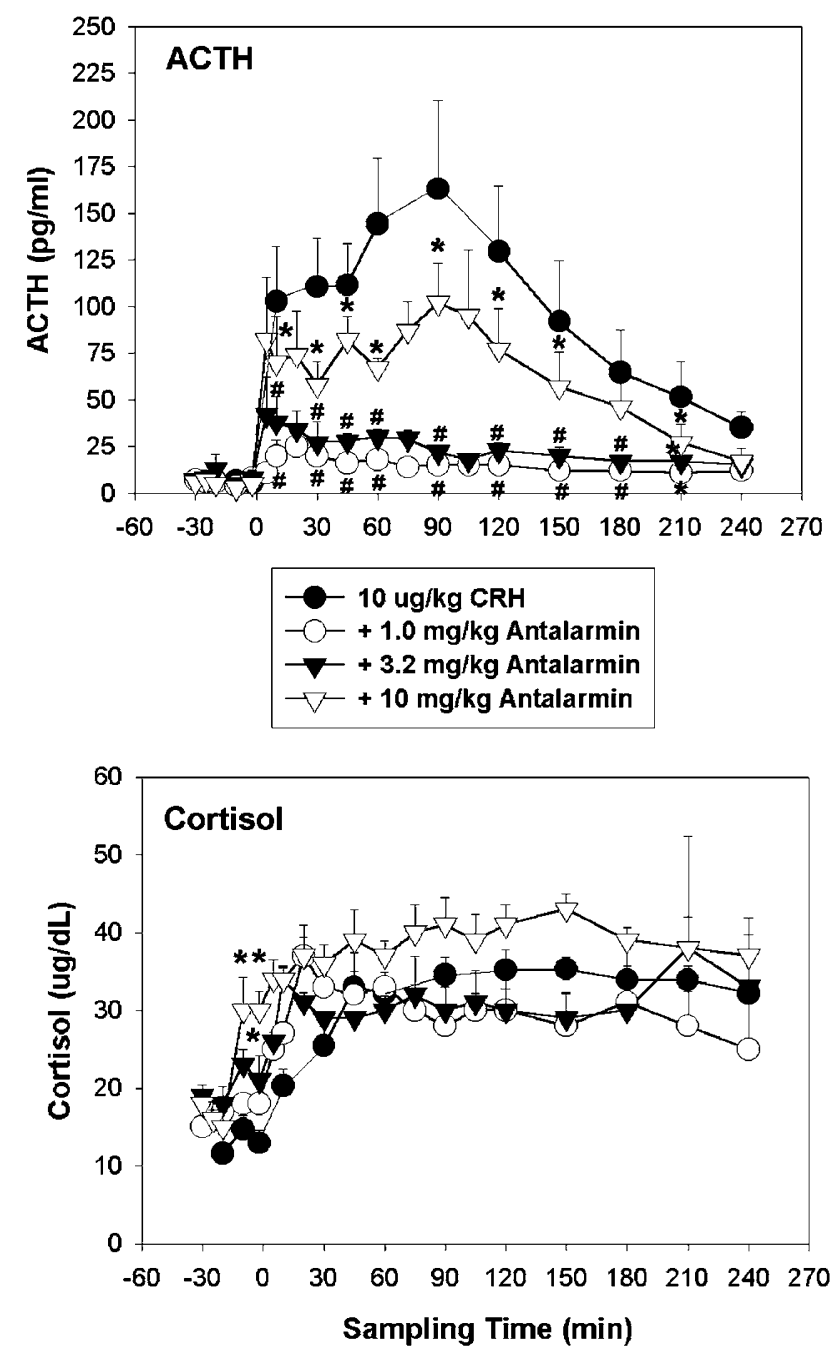

Figure 4 Averaged ACTH (upper panel) and cortisol (lower panel) levels in blood following i.v. administration of $10 \mu \mathrm{g} / \mathrm{kg} \mathrm{CRH}$ at time 0 . Male rhesus monkeys $(n=3)$ received $\mathrm{CRH}$ alone or after $15 \mathrm{~min}$ i.v. pretreatment with the $\mathrm{CRH}$ antagonist antalarmin (I.0, 3.2, or $10 \mathrm{mg} / \mathrm{kg}$ ). $\mathrm{CRH}$-stimulated $\mathrm{ACTH}$ levels were attenuated by prior treatment with antalarmin (upper panel: * vs CRH only; \# vs $\mathrm{CRH}$ and $10 \mathrm{mg} / \mathrm{kg}$ antalarmin, $p<0.05)$. The $\mathrm{CRH}$-stimulated release of cortisol was not affected by prior treatment with antalarmin (lower panel). However, there was a significant, dose-related elevation of cortisol levels measured in samples taken following antalarmin pretreatment, but prior to $\mathrm{CRH}$ administration (* vs no antalarmin pretreatment; ** vs $0, \quad 1.0$, and $3.2 \mathrm{mg} / \mathrm{kg}$ antalarmin pretreatment, $p<0.05$ ).

attenuated the cortisol or ACTH responses following the administration of $1 \mu \mathrm{g} / \mathrm{kg}$ CRH (data not shown).

Experiment 2. The effects of saline, antalarmin vehicle, and $10 \mathrm{mg} / \mathrm{kg}$ antalarmin on ACTH and cortisol were examined on several occasions (Figure 6). Neither saline nor vehicle injection differed in its effects on ACTH and cortisol release. However, i.v. administration of $10 \mathrm{mg} / \mathrm{kg}$ antalarmin resulted in a stimulation of the HPA axis. This effect appeared to peak on the second or third occasion that antalarmin was tested, and then diminished until it resembled a saline/vehicle-like response on the sixth and final test day. The increase in ACTH reached statistical significance the third time that antalarmin was given, 


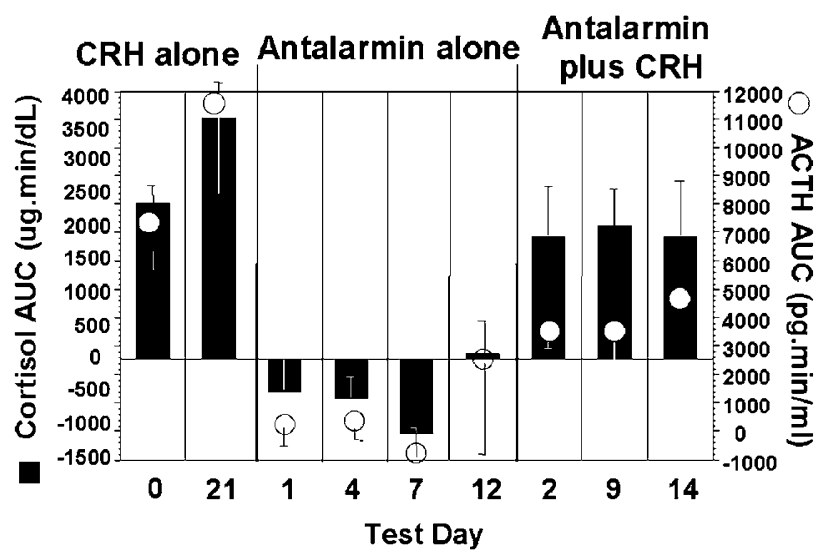

Figure 5 Comparison of the effects of repeated administration of $10 \mu \mathrm{g} /$ $\mathrm{kg} \mathrm{CRH}$ alone, $3.2 \mathrm{mg} / \mathrm{kg}$ antalarmin alone, and antalarmin given as a pretreatment to $\mathrm{CRH}$, on ACTH and cortisol release when tested over a 2I-day period $(n=4)$. Antalarmin when given alone did not differ from saline in its effects on cortisol and ACTH release. CRH when given alone stimulated cortisol and ACTH release. When antalarmin was administered prior to $\mathrm{CRH}$, antalarmin attenuated the ACTH response $(* * * 0.00 \mathrm{I})$, but not the cortisol response following $\mathrm{CRH}$ administration. The acute effects of $\mathrm{CRH}$, antalarmin, and $\mathrm{CRH}+$ antalarmin on $\mathrm{ACTH}$ and cortisol secretion were maintained when retested across multiple test days.

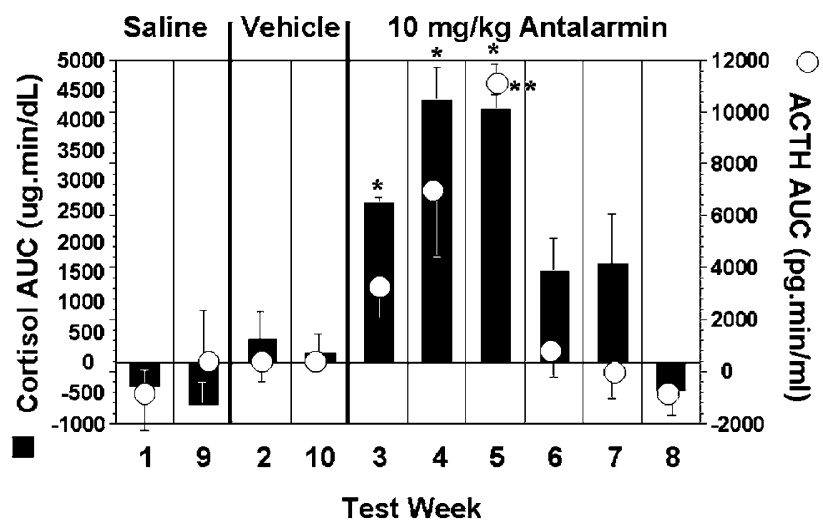

Figure 6 Comparison of the effects of repeated administration of saline, vehicle and $10 \mathrm{mg} / \mathrm{kg}$ antalarmin on ACTH and cortisol secretion when tested at weekly intervals $(n=3)$. Neither saline nor vehicle had any effect on ACTH and cortisol release. I.v. administration of $10 \mathrm{mg} / \mathrm{kg}$ antalarmin resulted in an acute stimulation of ACTH (** $p<0.05$; week 3 ) and cortisol $(* 0<0.05$; weeks I, 2, and 3) that diminished with repeated testing. The stimulation of stress hormone secretion was accompanied by behavioral sedation and lack of responsiveness to environmental stimuli, the extent and duration of which also diminished upon repeated exposure to antalarmin

whereas the increase in cortisol levels attained significance during the first, second, and third antalarmin tests $(p<0.05)$.

\section{Behavioral Effects of Antalarmin}

The highest dose of antalarmin that was administered $(10 \mathrm{mg} / \mathrm{kg})$ also produced profound changes in behavior for a period of $25-45 \mathrm{~min}$ following injection. Animals appeared sedated and either lay down in their cages or leaned on the cage interior. They exhibited drooling and were unresponsive to sound or motion. Gently touching the brow resulted in an eye blink with little or no movement of the head. Monkeys recovered normal function by 60-90 min following injection. The extent and duration of these behavioral changes diminished with repeated administration of $10 \mathrm{mg} / \mathrm{kg}$ antalarmin, following a similar time course to the changes in HPA response shown in Figure 6.

\section{DISCUSSION}

The prediction that antalarmin, a nonpeptidic $\mathrm{CRH}-\mathrm{R}_{1^{-}}$ selective antagonist, and astressin $\mathrm{B}$, a peptidic $\mathrm{CRH} \mathrm{R}_{1 \& 2^{-}}$ selective antagonist, would differ in their effects on pituitary $\mathrm{CRH}$ receptors following i.v. administration was supported by the results of this study. Astressin $\mathrm{B}$ produced an effective blockade of pituitary $\mathrm{CRH}$ receptors, attenuating the HPA response to exogenously administered $\mathrm{CRH}$, and decreasing both ACTH and cortisol levels in a dosedependent manner. However, pretreatment with antalarmin only attenuated the CRH-stimulated increase in ACTH release but had no effect on the $\mathrm{CRH}$-stimulated release of cortisol. The inhibitory effect of antalarmin on ACTH release diminished when the dose of antalarmin was increased.

\section{CRH + Antalarmin Pretreatment}

In the present study there was no evidence that antalarmin decreased CRH-stimulated cortisol levels at any time during the $4 \mathrm{~h}$ sampling period following the $\mathrm{CRH}$ injection. This lack of effect of antalarmin on CRH-stimulated cortisol levels may have been due simply to an incomplete blockade of $\mathrm{CRH}$ receptors by antalarmin, with the subsequent release of ACTH still being sufficient to stimulate cortisol release following a single injection of CRH. It appears more likely though that i.v. antalarmin pretreatment may actually have stimulated cortisol secretion, since plasma cortisol levels were already elevated prior to CRH injection in antalarmin-pretreated subjects. This paradoxical increase in cortisol secretion may have offset the inhibitory effect of the reduced ACTH levels on cortisol, with both effects occurring as a result of antalarmin pretreatment. There was no corresponding increase in ACTH levels, suggesting either that antalarmin has a direct effect on the adrenal cortex, or that antalarmin's effect on ACTH is more difficult to detect. An interesting corollary to this is the observation that repeated administration of $10 \mathrm{mg} / \mathrm{kg}$ antalarmin to monkeys that were initially antalarmin-naïve resulted in a significant elevation in cortisol on the first three occasions on which antalarmin was administered, but the increase in ACTH reached significance only after the third administration. There are similarities between the results described here and those reported by Habib et al (2000). In their study, antalarmin was administered orally (p.o.) to rhesus monkeys prior to presentation of an 'intruder paradigm', a 30-min exposure to another male monkey in which the two were separated only by a transparent barrier. Blood and CSF were taken under ketamine anesthesia $30 \mathrm{~min}$ later. As in the present study, only one $(20 \mathrm{mg} / \mathrm{kg}$ p.o.) of the four doses of antalarmin that were tested significantly attenuated the 
ACTH response to the social stressor and this effect was not dose-dependent, since a higher dose $(40 \mathrm{mg} / \mathrm{kg})$ did not produce a significant inhibition of ACTH secretion. The lack of an inhibitory effect of acute antalarmin administration on cortisol in the present study also concurs with earlier reports that chronic administration of antalarmin was necessary in order to detect reductions in basal corticosterone levels in rats (Bornstein et al, 1998; Wong et al, 1999).

\section{Behavioral Effects of Antalarmin and Astressin B}

In the few studies in which ACTH and/or corticosterone have been measured following antalarmin treatment, little or no effect of antalarmin on HPA measures was found (Deak et al, 1999; Wong et al, 1999). Yet anxiolytic activity of antalarmin has been reported in rats (Deak et al, 1999) and rhesus monkeys (Habib et al, 2000). Given the unusual HPA axis profile of antalarmin in the present study, and the lack of clear evidence of pituitary CRH-R1 receptor blockade in earlier studies, it seems reasonable to question whether antalarmin is producing it effects solely via CRH$\mathrm{R} 1$ receptors, or whether another mechanism is being recruited. This question has particular salience given the HPA and behavioral effects seen in association with antalarmin administration. When $10 \mathrm{mg} / \mathrm{kg}$ i.v. antalarmin was first administered to antalarmin-naïve rhesus monkeys, it had a clear stimulatory effect on cortisol. This effect was coupled with a period of profound sedation and behavioral unresponsiveness lasting 30-45 min. Both the HPA and behavioral changes that accompanied the administration of $10 \mathrm{mg} / \mathrm{kg}$ antalarmin diminished with repeated administration. I.v. antalarmin has also been shown to have transient reinforcing effects in rhesus monkeys across a range of doses, with some drug intakes resulting in visible intoxication (Broadbear et al, 2002). While there have been no prior reports associating antalarmin treatment with behavioral changes, it was noted by the authors that behavioral suppression by CP-154,526 may have been responsible for some of its effects on free exploration in mice (Griebel et al, 1998). In addition to the behavioral testing carried out in rhesus monkeys following oral antalarmin administration, antalarmin was also administered i.v. in the study by Habib et al, (2000). A single i.v. injection of $20 \mathrm{mg} / \mathrm{kg}$ antalarmin, which is double the maximum dose used in the present study, was administered in order to study antalarmin's pharmacokinetics. However, since this part of their study was carried out under ketamine anesthesia, behavioral observations were not possible. I.v. antalarmin clearly had acute sedative and HPA stimulatory effects in monkeys in the present study.

In contrast to antalarmin, astressin B produced neither behavioral nor HPA stimulatory effects at any dose tested. This may be because unlike antalarmin, astressin $B$ is unselective with respect to $\mathrm{CRH}$ receptor subtypes, and is unlikely to have ready access to the CNS following i.v. administration. Perhaps the most direct way to assess whether antalarmin's sedative and HPA stimulatory effects are mediated by central CRH-R1 receptors will be to similarly evaluate other nonpeptidic CRH-R1 antagonists as they become available.

\section{$\mathrm{CRH}+$ Astressin B Pretreatment}

As well as effectively blocking the ACTH and cortisol responses when administered 15 min prior to an injection of $\mathrm{CRH}$, astressin $\mathrm{B}(0.1 \mathrm{mg} / \mathrm{kg})$ was also active $24 \mathrm{~h}$ after administration. This concurs with results from adrenalectomized (ADX) rats, in which subcutaneous (s.c.) treatment with astressin B produced a dose-dependent suppression of ACTH release lasting in excess of $24 \mathrm{~h}$ (Rivier et al, 1999). Since astressin B is a bulky peptide, it is unlikely to have ready access to the CNS following systemic administration. A study carried out with astressin, another peptide from the same chemical series, showed that i.c. astressin $(10 \mu \mathrm{g})$, but not i.v. astressin $(10 \mu \mathrm{g})$, was effective at attenuating the delay in gastric emptying in rats following i.c. CRH $(0.6 \mu \mathrm{g})$ administration (Martinez et al, 1999). The effects of higher doses of i.v. astressin were not reported.

In the present study, using doses that produced equivalent reductions in $\mathrm{CRH}$-stimulated $\mathrm{ACTH}$ release (i.v.: $3.0 \mu \mathrm{g} / \mathrm{kg}$, i.c.: $0.01 \mu \mathrm{g} / \mathrm{kg}$ ) in the same subjects, we also determined that astressin B was approximately 300 times more potent following i.c. administration. This finding differs from those published previously, in which astressin (not astressin B), given via both i.c. and i.v. routes, was found to be equipotent in blocking the i.v. (not i.c., as discussed above) $\mathrm{CRH}$-induced delay in gastric emptying in rats (Martinez et al, 1999). In another study, rats were shown to have a reduced ACTH response to i.v. CRH $4 \mathrm{~h}$ after treatment with i.c.v. sheep anti-CRH (Turnbull and Rivier, 1998). At $4 \mathrm{~h}$, the plasma concentration of anti-CRH administered i.c.v. was $68-76 \%$ of the anti-CRH levels measured $4 \mathrm{~h}$ after i.v. administration, sufficient to produce a peripheral (pituitary) blockade of exogenous CRH. Turnbull and Rivier did not report whether shorter pretreatment times, when the plasma levels of anti-CRH following i.c.v. administration were much lower, were effective in blocking exogenous $\mathrm{CRH}$-induced ACTH release. The potency difference measured in the present study implies that astressin B may be concentrated in the hypophysial portal circulation, as the i.c. injection of $0.00001 \mathrm{mg} / \mathrm{kg}$ astressin $\mathrm{B}$ that attenuated the effect of i.v. $\mathrm{CRH}$ on ACTH would have been ineffective if given via the i.v. route. A number of antisera (Turnbull and Rivier, 1998), cytokines (Chen et al, 1997; Chen and Reichlin, 1999) and large molecules such as albumin (Reed and Woodbury, 1963) have been injected centrally and had their passage to the periphery traced. All are detectable in plasma within 530 min following injection. Clearly, these large molecules 'leak' out of the CNS to appear in the general circulation via a route that does not appear to differentiate between them. However, it has been shown that $\mathrm{CRH}$ is actively transported out of the CSF into blood (Martins et al, 1996). Astressin B, being a modified fragment of CRH, may also be a substrate for this mechanism, thus becoming concentrated in the cerebral vasculature, including the hypophysial portal system that supplies the anterior pituitary, soon after administration. This may explain the greater potency of astressin B following administration via the i.c. route $35 \mathrm{~min}$ prior to i.v. $\mathrm{CRH}$ administration. However, a simpler explanation could be that despite there being no measurable effect of anesthesization with methohexital on the subsequent CRH-stimulation of ACTH and 
cortisol, subthreshold effects of both methohexital and lowdose astressin B may have combined to increase the apparent potency of astressin B given via the i.c. route.

\section{Drug Self-Administration History}

There is also a question of whether having a history of cocaine or methohexital self-administration may have influenced the results of our study. We have published several studies showing that self-administered cocaine dosedependently stimulates the HPA axis, and about half of the monkeys in the present study have contributed data to these earlier papers. We have seen no evidence of changes in either baseline ACTH and cortisol activity, or changing trends in the monkeys' responses to self-administered cocaine and exogenous CRH injection (eg Broadbear et al, 1999a, b). Although studies in both humans (Buydens-Branchey et al, 2002) and rats (Zhou et al, 2003) have indicated that chronic cocaine exposure may change the responsiveness of the HPA axis (with higher cortisol levels being associated with highdose cocaine use in humans; tolerance to the HPAstimulating effects of cocaine reported in rats), the amount of cocaine administered in these published studies was probably or certainly much larger than that experienced by the monkeys described in the current study. In the present study, the available doses were small, access was limited to short periods of the day, and saline was substituted in at least $50 \%$ of the self-administration opportunities. The monkeys ate well, behaved normally, and appeared normal throughout this and the prior studies. In any event, it is not clear that a history of cocaine exposure would account for the differences observed between the effects of antalarmin and astressin $\mathrm{B}$ on the HPA axis response to $\mathrm{CRH}$ administration. Indeed, knowledge of the effects of $\mathrm{CRH}$ antagonists in subjects that have a history of substance use may be directly relevant to the investigation of $\mathrm{CRH}$ antagonists for the treatment of substance abuse disorders.

In summary, the data presented in this study show that the unselective, peptidic $\mathrm{CRH}$ antagonist, astressin B, effectively attenuated the $\mathrm{CRH}$-stimulated $\mathrm{ACTH}$ and cortisol responses. In contrast, antalarmin, despite its apparent selectivity and affinity for $\mathrm{CRH}-\mathrm{R} 1$ receptors in vitro, appears to have a self-limiting effect at pituitary CRH-R1 receptors in vivo following acute administration. Paradoxically, antalarmin itself produced a stimulation of the HPA axis and profound behavioral sedation when administered at a high dose. Why should these two CRH-antagonists show such different profiles in the same experimental paradigm? Since astressin B is water-soluble and antalarmin is administered as an emulsion, it is possible that antalarmin is poorly distributed and at higher doses has nonselective effects on other physiological systems. Alternatively, the behavioral and HPA effects of antalarmin could be a consequence of its simultaneous blockade of both central and peripheral CRH-R1 receptors, revealing a novel profile of activity for this nonpeptidic R1-selective antagonist.

\section{ACKNOWLEDGEMENTS}

We thank Nicholas Jones, Karen Wiesenauer, Deborah Huntzinger, Sarah Pilkington, Ave Childrey, Akemi Ueda, and Laurie McDowell (University of Michigan) and D Kirby, L Lahrichi, and R Kaiser (Salk Institute) for their expert technical assistance. This work was supported by the United States Public Health Service Grants DA 09161 and DA 00254 (University of Michigan) and DK 26741 (Salk Institute). Results from this paper were first presented at the annual meeting of ISPNE, Melbourne, Australia, 2000.

Animals used in these studies were maintained in accordance with the University of Michigan Committee on Animal Care and Guidelines of the Committee on the Care and Use of Laboratory Animal Resources, National Health Council (Department of Health, Education and Welfare, ISBN 0-309-05377-3, revised 1996).

\section{REFERENCES}

Bornstein SR, Webster EL, Torpy DJ, Richman SJ, Mitsiades N, Ingel $\mathrm{M}$ et al (1998). Chronic effects of non-peptide corticotropin-releasing hormone type I receptor antagonist on pituitary-adrenal function, body weight and metabolic regulation. Endocrinology 139: 1546-1555.

Broadbear J, Winger G, Woods J (1999a). Cocaine responding in rhesus monkeys: pharmacological antagonism of the HPA effect. J Pharmacol Exp Ther 290: 1347-1355.

Broadbear JH, Winger GD, Cicero TJ, Woods JH (1999b). Effects of response contingent and non-contingent cocaine injection on HPA activity in rhesus monkeys. J Pharmacol Exp Ther 290: 393-402.

Broadbear JH, Winger GD, Rivier J, Rice K, Woods JH (2002). Antalarmin, a putative CRH-R1 antagonist, has transient reinforcing effects in rhesus monkeys. Psychopharmacology 164: 268-276.

Buydens-Branchey L, Branchey M, Hudson J, Dorota Majewska M (2002). Perturbations of plasma cortisol and DHEA-S following discontinuation of cocaine use in cocaine addicts. Psychoneuroendocrinology 27: 83-97.

Chen G, Reichlin S (1999). Mechanisms by which blood levels of interleukin-6 (IL-6) are elevated after intracerebroventricular injection of IL-1 $\beta$ in the rat: neural versus humoral control. Endocrinology 140: 5549-5555.

Chen Y, Mansbach R, Winter S, Brooks E, Collins J, Corman M et al (1997). Synthesis and oral efficacy of a 4-(butylethylamino)pyrrolo[2,3- $\left.d^{\prime}\right]$ pyrimidine: a centrally active corticotropin-releasing factor1 receptor antagonist. J Med Chem 40: 1749-1754.

Deak T, Nguyen K, Ehrlich A, Watkins L, Spencer R, Maier S et al (1999). The impact of the nonpeptide corticotropin-releasing hormone antagonist antalarmin on behavioral and endocrine responses to stress. Endocrinology 140: 79-86.

Goeders NE (1997). A neuroendocrine role in cocaine reinforcement. Psychoneuroendocrinology 22: 237-259.

Goeders NE, Guerin GF (2000). Effects of the CRH receptor antagonist CP-154,526 on intravenous cocaine self-administration in rats. Neuropsychopharmacology 23: 577-586.

Griebel G, Perrault G, Sanger D (1998). Characterization of the behavioral profile of the non-peptidic CRF receptor antagonist $\mathrm{CP}-154,526$ in anxiety models in rodents. Comparison with diazepam and buspirone. Psychopharmacology 138: 55-66.

Griebel G, Simiand J, Steinberg R, Jung M, Gully D, Roger P et al (2002). 4-(2-Chloro-4-methoxy-5-methylphenyl)- $N$-[(1S)-2-cyclopropyl-1-(3-fluoro-4-methylphenyl)ethyl]5-methyl- $\mathrm{N}$-(2-propynyl)1,3-thiazol-2-amine hydrochloride (SSR125543A), a potent and

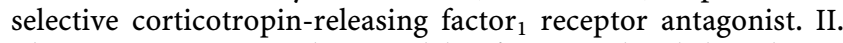
Characterization in rodent models of stress-related disorders. $J$ Pharmacol Exp Ther 301: 333-345.

Gulyas J, Rivier C, Perrin M, Koerber S, Sutton S, Corrigan A et al (1995). Potent, structurally constrained agonists and competitive 
antagonists of corticotropin-releasing factor. Proc Natl Acad Sci USA 92: 10575-10579.

Habib K, Weld K, Rice K, Pushkas J, Champoux M, Listwak S et al (2000). Oral administration of a corticotropin-releasing hormone receptor antagonist significantly attenuates behavioral, neuroendocrine, and autonomic responses to stress in primates. Proc Natl Acad Sci USA 97: 6079-6084.

Hernandez J-F, Kornreich W, Rivier C, Miranda A, Yamamoto G, Andrews J et al (1993). Synthesis and relative potencies of new constrained CRF antagonists. J Med Chem 36: 2860-2867.

Holsboer F (1998). The rationale for corticotropin-releasing hormone receptor (CRH-R) antagonists to treat depression and anxiety. $J$ Psychiat Res 33: 181-214.

Lu L, Liu D, Ceng X, Ma L (2000). Differential roles of corticotropin-releasing factor receptor subtypes 1 and 2 in opiate withdrawal and in relapse to opiate dependence. Eur J Neurosci 12: 4398-4404.

Martinez V, Rivier J, Tache Y (1999). Peripheral injection of a new corticotropin-releasing factor (CRF) antagonist, astressin, blocks peripheral CRF- and abdominal surgery-induced delayed gastric emptying in rats. J Pharmacol Exp Ther 290: 629-634.

Martins J, Kastin A, Banks W (1996). Unidirectional specific and modulated brain to blood transport of corticotropin-releasinghormone. Neuroendocrinology 63: 338-348.

McCarthy J, Heinrichs S, Grigoriadis D (1999). Recent advances with the CRF1 receptor: design of small molecule inhibitors, receptor subtypes and clinical indications. Curr Pharm Des 5: 289-315.

McEwen B (2000). Allostasis and allostatic load: implications for neuropsychopharmacology. Neuropsychopharmacology 22: 108-124.

Menzaghi F, Howard R, Heinrichs S, Vale W, Rivier J, Koob G (1994). Characterization of a novel and potent corticotropin-releasing factor antagonist in rats. J Pharmacol Exp Ther 269: 564-572.

Nemeroff C (1996). The corticotropin-releasing factor (CRF) hypothesis of depression: new findings and new directions. Mol Psychiatry 1: 336-342.

Reed D, Woodbury D (1963). Kinetics of iodide, sucrose, inulin and radio-iodinated serum albumin in the central nervous system and cerebrospinal fluid of the rat. J Physiol 169: 816-850.

Rivier CL, Grigoriadis DE, Rivier JE (2003). Role of corticotropinreleasing factor receptors type 1 and 2 in modulating the rat adrenocorticotropin response to stressors. Endocrinology 144: 2396-2403.

Rivier J, Kirby D, Lahrichi S, Corrigan A, Vale W, Rivier C (1999). Constrained corticotropin releasing factor antagonists (astressin analogues) with long duration of action in the rat. J Med Chem 42: 3175-3182.

Rivier J, Rivier C, Vale W (1984). Synthetic competitive antagonists of corticotropin-releasing factor: effect on ACTH secretion in the rat. Science 224: 889-891.

Schulz D, Mansbach R, Sprouse J, Braselton J, Collins J, Corman M et al (1996). CP-154,526: a potent and selective nonpeptide antagonist of corticotropin releasing factor receptors. Proc Natl Acad Sci USA 93: 10477-10482.

Shaham Y, Erb S, Leung S, Buczek Y, Stewart J (1998). CP-154,526, a selective, non-peptide antagonist of the corticotropin-releasing factor $_{1}$ receptor attenuates stress-induced relapse to drug seeking in cocaine- and heroin-trained rats. Psychopharmacology 137: 184-190.

Tallarida RJ, Murray RB (1987). Manual or Pharmacologic Calculations with Computer Programs. Springer-Verlag: New York.

Turnbull A, Rivier C (1998). Intracerebroventricular passive immunization. II. Intracerebroventricular infusion of neuropeptide antisera can inhibit neuropeptide signaling in peripheral tissues. Endocrinology 139: 128-136.

Webster E, Lewis D, Torpy D, Zachman E, Rice K, Chrousos G (1996). In vivo and in vitro characterization of antalarmin, a nonpeptide corticotropin-releasing hormone $(\mathrm{CRH})$ receptor antagonist: suppression of pituitary ACTH release and peripheral inflammation. Endocrinology 137: 5747-5750.

Wong M-L, Webster E, Spokes H, Phu P, Ehrhart-Bornstein M, Borstein $S$ et al (1999). Chronic administration of the nonpeptide $\mathrm{CRH}$ type 1 receptor antagonist antalarmin does not blunt hypothalamic-pituitary-adrenal axis responses to acute immobilization stress. Life Sciences 65: PL53-PL58.

Zhou Y, Spangler R, Schlussman SD, Ho A, Kreek MJ (2003). Alterations in hypothalamic-pituitary-adrenal axis activity and in levels of proopiomelanocortin and corticotropin-releasing hormone-receptor 1 mRNAs in the pituitary and hypothalamus of the rat during chronic 'binge' cocaine and withdrawal. Brain Res 964: 187-199. 